\title{
THE ASPARTAME CONTROVERSY OF 1981 The Hidden Truth Behind the Not-So-Sweet Artificial Sweetener
}

Morgan Sykes

N inety-eight out of 196 infant mice died after exposure to aspartame in a 1977 Food and Drug Administration the Bressler Report, revealed these FDA findings as well as numerous other troubling data submitted to the FDA by the primary producer

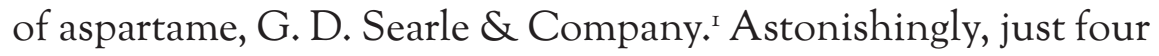
years later, the FDA approved aspartame for human consumption in dry foods, and two years after that authorized its use in carbonated beverages. To this day, every time someone consumes a diet soda, they are putting this potentially toxic chemical into their body.

For the next several decades, the use of artificial sweeteners, especially aspartame, remained a popular topic of concern. Substances sweeter than sugar with few to no calories initially seemed like a dream come true, but unfortunately many harmful side effects tarnished the reputation of these chemicals. While the FDA restricted many uses of these sweeteners over the years, aspartame continues to be one of the most frequently used food additives since 1983 . Shockingly, many people are unaware of the chemical's potentially harmful long-term effect on regular users, both animal and human.

I Mark D. Gold, "Recall Aspartame as a Neurotoxic Drug," FDA Docket O2P-03I7, 2003. http://www.fda.gov/ohrms/DOCKETS/dailys/o3/Jano3/or2203/o2P-o317_emcoooig6.txt. 


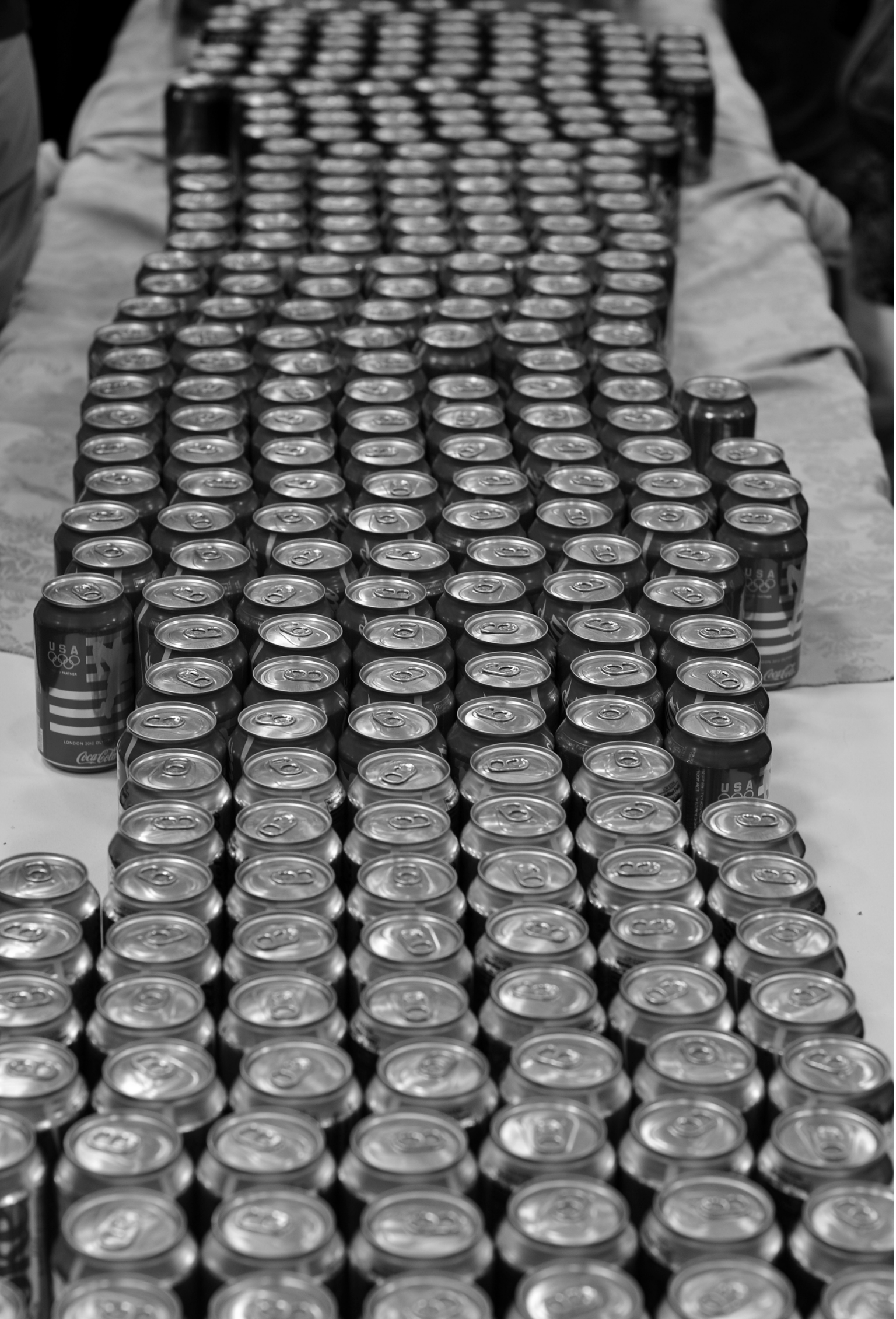


Much has been written about aspartame and its health effects over the past several decades. Newspapers conducted interviews and undertook investigations related to the possible detrimental consequences. Academic journals thoroughly analyzed the content and chemical makeup of the substance and numerous studies were completed recording the effects of aspartame in animals. For example, in 1993 Dr. Morando Soffritti conducted the Ramazzini study using I,800 rats over a thirty-six-month period. The Italian scientist monitored the rodents for three years instead of two to better simulate the corresponding age that cancer develops in most humans. His findings included many cases of leukemia, lymphoma, and kidney cancers, thus further emphasizing the potential dangers of aspartame. ${ }^{2}$

Previous authors have focused on the content of the drug and personal testimony related to its use. Sweet Poison, by Janet Starr Hull, elaborates on the author's personal experiences with aspartame and the negative impact it had on her life. Her symptoms included severe headaches, vision problems, and regular nausea. ${ }^{3}$ Many people affected by aspartame offer to share their stories, and newspaper articles often question the safety of the additive. ${ }^{4}$ Empty Pleasures: From Saccharin to Splenda by Carolyn de la Pena illustrates the evolution of artificial sweeteners, their effects on the human body, and the history of the use of sugar substitutes in America. Carolyn La Pena, author of Empty Pleasures: The Story of Artificial Sweetners From Saccharin to Splenda explains that when the body perceives artificial sweeteners as sugar, the lack of calories and energy actually trick it into feeling empty and cause more food cravings. This lack of fulfillment defeats the purpose of eating low-calorie foods. ${ }^{5}$ In this article, I explore not only the published record on aspartame's safety and toxicity, but also the reasons this potentially dangerous chemical remains legal today.

2 Melanie Warner, “The Lowdown on Sweet?" New York Times, February I2, 2006, sec. Business/Your Money, February ı2, 2006, http://www.nytimes.com/2006/o2/r2/ business/yourmoney/r2sweet.html?pagewanted=all.

3 Janet S. Hull, Sweet Poison: How the World's Most Popular Artificial Sweetener Is Killing Us (Far Hills, NJ: New Horizon Press, 1998).

4 So much controversy has arisen from aspartame that websites, blogs, and health forums were created solely to share stories about the negative side effects of the chemical. Websites such as www.aspartamecontroversy.com publish emails sent in by consumers. Also the FDA conducts studies based on consumer experiences, analyzing the side effects and correlations to aspartame.

5 Carolyn D. La Pena, Empty Pleasures: The Story of Artificial Sweeteners From Saccharin to Splenda (Greensboro, NC: The University of North Carolina Press, 20Io). 
The considerable amount of evidence concerning the hazards of aspartame might lead one to conclude that an FDA ban exists on the substance. However, I argue that corruption within the government and big business led to the FDA's approval of aspartame. Evidence of corruption found in government documents, court trials, newspapers, and academic journals forms a solid foundation of facts to support these claims.

The purpose of this research is to analyze the validity of the FDA's approvals and further investigate the side effects of aspartame. While some consumers are aware of the possible consequences of this artificial sweetener, others remain unaware of the problems. Further understanding of why the chemical was initially approved can raise consciousness about food issues more generally and hopefully cause consumers to scrutinize their food ingredients. As technology increases, our society puts less emphasis on food safety and instead blindly trusts the FDA. Today, most people rely on simplicity and convenience of food rather than understanding where it comes from and what it actually contains.

Although numerous studies were conducted documenting negative findings concerning the effects of aspartame, the sweetener remains legal, partially due to the political power of companies who manufacture it. In 1981, Ronald Reagan, with help from members of his transition team, including the CEO of G. D. Searle, Donald Rumsfeld, appointed Dr. Arthur Hull Hayes Jr. as the new FDA commissioner. Just weeks later, Rumsfeld submitted a reevaluation of aspartame and Hayes, ignoring the recommendations of several doctors, approved the substance for human consumption. ${ }^{6}$ This article argues that the numerous conflicts of interest within the government and big business allowed aspartame to be approved for human consumption even when it was demonstrated to be a carcinogen and a cause of other harmful side effects in animals. Rumsfeld was able to use political power and connections in Washington to influence key decisions of the FDA in the early ig8os.

\section{Saccharin: The Original Artificial Sweetener}

The artificial sweetener saga began when saccharin was inadvertently discovered in 1879 . While scientists were intrigued, the

6 Ashley Nill, "The History of Aspartame," (Food and Drug Law/Third Year Paper Harvard Law School, Cambridge MA, 2000), accessed February 15, 2014,. http://dash.harvard.edu/bitstream/handle/I/8846759/Nill,_Ashley_-The_History_of_ Aspartame.html?sequence $=6$. 
popularity of this sweetener did not catch on with the public until the sugar shortage in World War I.7 As saccharin gained popularity, its success encouraged other manufacturers to create more artificial sweeteners. In I95I, cyclamate was approved as a food additive and the combination of cyclamate and saccharin became the country's most popular sugar substitute. Containing many fewer calories and being one-tenth the price of pure sugar, this combination gained the immediate attention of manufactures. Sweet'N Low was created in I957 and was immediately advertised as a substance to help "ladies keep their girlish figures." ${ }^{8}$ For the next decade, cyclamate and saccharin continued to thrive as the first diet sodas were produced. Health concerns were noted, but widely ignored until the Pure Food and Drug Act forced the FDA to temporarily ban saccharin after links with cancer were documented and exposed. ${ }^{9}$

In 1977 , a Canadian study brought attention to saccharin as its results showed an overwhelming amount of bladder cancer found in Charles River lab rats as a result of saccharin intake. After this research, the Canadian government decided to ban saccharin. ${ }^{\text {I0 }}$ The findings of the study also made the FDA take notice and propose a ban on saccharin. While there was much public opposition, the FDA's hands were tied due to the Delaney Clause within the I958 Food Additive Amendment. This clause declares that if a chemical has been found to cause cancer in animals, it cannot be used as a food additive. To the surprise of the FDA, a vast amount of public outcry, especially from the diabetic community, made Congress postpone the ban until they could further discuss the product. ${ }^{\text {II }}$

With so much public opposition, Congress decided to delay the ban on saccharin until further tests could be conducted. Although the ban was postponed, Congress passed the Saccharin Study and Labeling Act, which required all products containing saccharin to

7 Nill, "History,"

8 “The Story of Sweet'N Low," Sweet'N Low, accessed February I7, 20I4, http:// www.sweetnlow.com/brand.

9 Wallace Janssen, "The Story of the Laws Behind the Labels," US Food and Drug Administration, accessed February 17, 20I4, http:/www.fda.gov/AboutFDA/ WhatWeDo/History/Overviews/ucmo56044.htm.

Io "Epidemiological Studies of Saccharin: Addendum", 1977, https://www. princeton.edu/ ota/disk3/1977/7702/770213.PDF.

II Richard Merrill, "Regulating Carcinogens in Food: A Legislator's Guide to the Food Safety Provisions of the Federal Food, Drug, and Cosmetic Act," Michigan Law Review 77, (1978): I9I-I95. http://www.jstor.org/stable/I287920. 
nclude a warning label, declaring the product as a carcinogen in

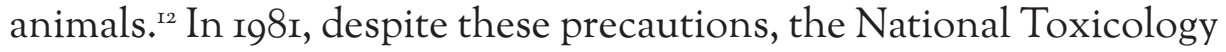
Program described saccharin as "reasonably anticipated to be a human carcinogen based on sufficient evidence of carcinogenicity in animals." ${ }_{13}$ With the ominous labels, saccharin lost much of its popularity and demand. For G. D. Searle, this ban marked the beginning of a golden opportunity to take control of the artificial sweetener market with their new product, aspartame.

\section{An Accidental Discovery Leads to a Gold Mine}

In December 1965, James Schlatter unintentionally discovered aspartame and his company, G. D. Searle, immediately began testing the chemical hoping for success. Aspartame is an odorless powder made up of two amino acids, L-aspartic acid and L-phenylalanine and was found to be one hundred eighty times sweeter than sugar, with few calories. Although aspartame was not as sweet as its former competitor saccharin, its creators hoped to market it as a safer alternative. G. D. Searle published the findings in Science Magazine in 1970. ${ }^{14}$ While other sugar substitutes were being scrutinized for links with cancer, Searle wanted aspartame to be approved so it could break into this competitive, lucrative market. A memo written within the company explained their strategy of getting aspartame approved: "The basic philosophy of our approach to food and drugs should be to try to get them to say 'Yes,'... this would also help bring them into subconscious spirit of participation., ${ }^{15}$

G. D. Searle applied for the first FDA approval of aspartame on March 5, 1973, and Dr. Martha M. Freeman of the FDA Division of Metabolic and Endocrine Drug Products was not impressed. In an FDA memorandum, she expressed her concern with the studies conducted, especially the single dose studies. According to Dr. Freeman, results from single dose testing could not generate accurate predictions of regular consumption. Freeman concluded that the

I2 Times Staff, "A History of Saccharin," Los Angeles Times, December 27, 20I0. http://articles.latimes.com/2010/dec/27/health/la-he-nutrition-lab-saccharintimelin20IOI227.

I3 “Saccharin,” National Toxicology Program, accessed,February I7, 20I4, http:// www.ncbi.nlm.nih.gov/pmc/articles/PMCi637197/

I4 Marion R. Cloninger and Ruth E. Baldwin, "Aspartylphenylalanine Methyl Ester: A Low-Calorie Sweetener,” Science I70 (I970): 8I-82. http://www.jstor.org/ stable/ı730I76.

I5 Gold, "Recall Aspartame." 
information submitted was insufficient evidence of clinical safety. ${ }^{16}$ In 1974 , the FDA rejected Freeman's recommendation and approved aspartame for use in dry foods.

While the FDA found many irregularities in G. D. Searle's sloppy reports, the approval was granted based on an assumption of safety since the chemical makeup of aspartame included two naturally occurring amino acids found in the human body. ${ }^{17}$ Even with naturally occurring ingredients, not everyone was convinced of the new sugar substitute's safety. The simple assumption of safety without scientific evidence was not sufficient proof for many doctors. Neuroscientist Dr. John Olney and consumer attorney James Turner were appalled by the approval and immediately filed a formal objection to the authorization. Dr. Olney had dedicated his life to brain damage research after graduating from Washington University School of Medicine. ${ }^{18}$ Turner represented businesses and consumers in cases regarding food, drug, health, and environmental regulations. ${ }^{19}$ Working together, they strongly opposed the approval of aspartame for use in dry foods and demanded an appeal. Dr. Olney and Turner were especially concerned with aspartame's potential for causing brain damage and other harmful effects in children. They did not feel significant research in either of those fields had been conducted. Without indisputable evidence of safety, these specialists were not comfortable with this product being on the market. ${ }^{20}$ While the FDA did find discrepancies in the studies, they concluded that the problems did not provide adequate cause to overturn the safety results. ${ }^{21}$

In 1977 , aspartame was pulled from market until the completion of an FDA inquiry questioning the safety results documented in G. D. Searle's studies. Richard Merrill, FDA Chief Counsel, suggested

I6 Martha M. Freeman, "The Role of Clinical Guidelines in Research: FDA's Viewpoint,” The Journal of Clinical Pharmacology I7 (I977): 682-685.

I7 "NutraSweet-Not So Neat," Off Our Backs I4, no. 8 (I984): 8. http://www.jstor. org/stable/2579446I.

I8 John Olney, "Medicine Alumni Society: Alumni Interview," The University of Iowa, accessed, February I6, 20I4, http:/www.healthcare.uiowa.edu/alumni/ interviews/olney_john.html.

I9 Swankin and Turner: Attorneys at Law, "James S. Turner," accessed February I6, 20I4,, http://www.swankin-turner.com/jim.html.

20 “Controversy Over New Sweetener," Science News iı6, no. 6 (I979) Io3. http:// www.jstor.org/stable/3964327.

2I US Food and Drug Administration, Food Additive Approval Process Followed for Aspartame, June 1987, http://archive.gao.gov/d28t5/133460.pdf. 
a grand jury be appointed to further investigate the company's shady past. The FDA unit began examining fifteen studies: nine were deemed crucial, objectors suggested three, and the last three were chosen at random. A common theme among the studies was a lack of quality control. The research was not uniformly performed and reviewed, causing the data to be extremely inconsistent and inaccurate. Lab rat feeding methods involved serving nonhomogeneous samples where the aspartame was not dissolved in the food and could be separated and avoided by the subjects. Since the food sample was not homogeneous, the rats often ate around the aspartame, skewing the results. Another problem noted with the data was missing tissue samples lost during autolysis. ${ }^{22}$ Omitted data in research is an immediate red flag, even when the results of the missing findings cannot be determined. Lastly, one study claimed that one researcher conducted 329 fetal examinations in two days. The FDA team found this feat impossible if done adequately and accurately. The main concerns regarding all fifteen studies surrounded missing details in reports and the variable conditions of testing. The FDA decided to appoint an independent organization to further investigate the irregularities and reliability of Searle's studies concerning safety. ${ }^{23}$

Under Merrill's request, United States Federal Attorney Samuel Skinner was designated to head the investigation into the irregularities found in G. D. Searle's studies. The five year statute of limitations was quickly approaching, however, so the investigation needed to be done rapidly. After the statute of limitations ran out, the investigation and any possible penalty could not be pursued. Skinner was appointed to act quickly and efficiently on the case in order to reveal the truth about aspartame's safety. In the midst of the investigation, the law firm Sidley Austin, G. D. Searle's attorneys, approached Skinner and offered him a position in their company. Through persuasion and financial compensation, Sidley Austin managed to convince Skinner to relinquish his current position within the federal attorney's office, leaving the investigation without a leader. Lacking an immediate replacement, the trial was stalled and eventually

22 Autolysis is defined as the self-destruction of cells by enzymes found within the body. Healthy cells through the process of autolysis will often digest deformed or injured cells that are no longer able to absorb nutrients.

23 Milton J. Socolar, "Report to the Honorable Howard M. Metzenbaum. U.S. Senate: Food and Drug Administration Food Additive Approval Process Followed for Aspartame" (GAO/HED-87-46) (Washington, DC: U.S. Government Accountability Office,I987), http://archive.gao.gov/d28t5/133460.pdf. 
dismissed after the statute of limitations expired. ${ }^{24}$

\section{Rumsfeld Hired to Save G.D. Searle}

Aware that they faced adversity, G. D. Searle hired Donald Rumsfeld as their new CEO with hopeful anticipation that his political power and leadership could revamp the company. Rumsfeld was no stranger to Washington. In 1962, he ran for Congress in the $13^{\text {th }}$ Congressional district of Illinois on the Republican ticket and won in a landslide. During his time in Congress, colleagues described him as a sharp and aggressive politician. He quickly grew tired of his congressional position and after holding other posts became the youngest secretary of defense in 1975. When Democrat Jimmy Carter took office in 1977 , Rumsfeld was left without a job and decided to accept the position with G. D. Searle. ${ }^{25}$ With multiple connections in Washington, Rumsfeld promised to stop at nothing until the company was out of trouble and thriving once again. Part of Rumsfeld's plan was selling off underperforming divisions and focusing on products that were in high demand. He placed a big focus on aspartame, but approval was necessary before the sugar substitute could become a moneymaker. ${ }^{26}$

Following the release of the Bressler Report in 1977, Searle was once again under the scrutiny of the FDA. An FDA task force headed by Jerome Bressler examined three crucial studies and found an abundance of questionable evidence and indisputable neglect by Searle's scientists. Delayed autopsies left many dead rats with insufficient standards of quality for valid observation, so they were simply discarded. In the reports, several animals were noted dead and then referenced again as alive weeks later. An infectious disease, which plagued many of the animals in question, remained unreported. The pathology details of thirty rats submitted to the FDA were not in agreement with the documentation recorded during the actual study. Also, the animals studied were not permanently labeled, allowing numerous instances of inaccurate documentation and uncertainty. In one experiment, the details of fifteen fetuses examined were absent in

24 Ed Metcalfe, "Sweet Talking," The Ecologist 30 (2000): 16. http://search. proquest.com/docview/743764035.

25 Andrew Cockburn, Rumsfeld: His Rise, Fall, and Catastrophic Legacy (New York: Simon and Schuster, 2007) 5I-75.

26 Stephen Chapman, "Can Rumsfeld Add Another Line To A Strong Resume?" Chicago Tribune, February 15, I987, C3. http://articles.chicagotribune.com/1987-02I5/news/870ri20628___donald-rumsfeld-white-house-secret-service. 
the reports submitted to the FDA. Standards and control groups for each study were not set until after many experiments had begun, and several protocols changed midway through the examinations. ${ }^{27}$ None of these major discrepancies were reported to the FDA. Jerome Bressle reported to the Senate:

Because of the importance of this study, why wasn't greater care taken? The study is highly questionable because of our findings. Why didn't Searle, with their scientists, closely evaluate this, knowing fully well that the whole society, from the youngest to the elderly, from the sick to the unsick, everyone will have access to this product. ${ }^{28}$

The results of the Bressler Report led the FDA to launch a new investigation to corroborate its conclusions. An FDA toxicologist, Jacqueline Verrett, led a five member task force. This team was faced with the difficult task of proving that G.D. Searle purposefully manipulated evidence in order to gain FDA approval of aspartame. The problem Verrett encountered was that the experiments and data were so flawed and inconsistent that no specific incidences of misconduct could be identified. Although the validity of many studies was clearly uncertain, no intentional falsification of data could be proven. Regardless of G. D. Searle's inadequate experiments, the FDA was unable to indisputably substantiate that the company had deliberately submitted inaccurate facts. According to her reports before the Senate, Verrett was frustrated by the FDA's inability to act based on the findings in the Bressler Report. She explained that her assignment was not to question the validity of the data submitted by G. D. Searle, but to prove intentional deceit by Searle's scientists. Due to the substantial number of inconsistencies during their research, pinpointing specific details of falsified information was impossible. She concluded by stating that regardless of the motives behind the conflicting and incomplete data, she firmly believed that the safety of aspartame had not been satisfactorily confirmed and should be studied further. ${ }^{29}$

Under pressure by Olney and Turner, the FDA finally held a public board of inquiry in 1979 to review health claims concerning aspartame. The two issues under scrutiny were whether aspartame

27 Gold, "Recall Aspartame," FDA, http://www.fda.gov.

28 Jerome Bressler, interview by Robert A. Tucker, History of the US Food and Drug Administration, April 23, I999, http:/www.fda.gov.

29 Gold, "Recall Aspartame." 
increased the risk of brain damage or mental retardation and if ingestion of aspartame led to brain tumors in animals, namely rats. After analyzing the issues, the board was to decide if this additive should continue to be used in foods, and if the approval was not revoked, if warning labels should be required on products containing aspartame. The board met three times and discussed both issues, placing emphasis on addressing the risks of aspartame as a known carcinogen. With insufficient evidence of aspartame's safety, the board concluded that the artificial sweetener should remain off the market until further tests were conducted to confirm adequate safety standards before approval was granted. ${ }^{30}$ The board was particularly alarmed by two particular studies known as $E_{33}$ and $E_{70}$. In $E_{33}, 320$ rats were fed aspartame. Compared to the control group, the rats exposed to the chemical suffered from a significantly higher number of brain tumors. E70 revealed abnormally high amounts of brain tumors in both the aspartame and control groups, leading the board to believe that both groups had exposure to the substance. Based upon the evidence available, in 1980 the Public Board of Inquiry unanimously agreed to reject the approval of aspartame until further testing could be completed. ${ }^{3 \mathrm{I}}$

\section{The Revolving Door of FDA Employees Begins to Turn}

As Rumsfeld promised, he was not opposed to using political influence in order to help his company. As a member of Ronald Reagan's transition team, his power in Washington was once again evident. ${ }^{22}$ Reagan was sworn into office on January 20 , I98I, and the next day G. D. Searle resubmitted their request for approval of aspartame as a food additive. By using his political prestige and experience shortly after the new President's inauguration, Rumsfeld encouraged Reagan to replace the current FDA commissioner, Jere Goyan. Reagan, under the guidance of Rumsfeld, appointed Arthur Hull Hayes Jr. as the new FDA commissioner in April r98ı. Hayes had no experience with food additives before accepting his job with the

30 Todd R. Smyth, "The FDA's Public Board of Inquiry and the Aspartame Decision," Indiana Law Journal 58 (1983): 633-635. http://www.repository.law.indiana. edu/cgi/viewcontent.cgi? article $=2268 \&$ context $=i l j$.

3I “Controversy Over New Sweetener,” Science News ir6, no. 6 (I979): Io3. http:// www.jstor.org/stable/3964327.

32 Established in 1963 , The Presidential Transition Act of 1963 allowed for a transition team to be appointed for each new president to aide the transfer of power from one administration to the next. 
FDA. Despite his lack of qualifications, Hayes did have a relationship with Rumsfeld from working together on chemical warfare for the Department of Defense. Just two months after his appointment on July 15, 1981, Hayes disregarded the unanimous decision and recommendations of the Public Board of Inquiry by approving aspartame for use in dry foods. ${ }^{33}$ Hayes did admit that he wished more studies had been completed, but he did not think there was enough evidence present to delay the manufacturing of aspartame any longer. "I'm not prepared to say there is no risk from aspartame, but I thought it had been demonstrated that there was not a significant risk," Hayes concluded. ${ }^{34}$ G. D. Searle immediately began marketing aspartame as a safe alternative to saccharin. Products containing aspartame did need to be clearly marked, but unlike saccharin, did not require a warning label stating possible side effects. Even with their recent success, G. D. Searle was not satisfied with the approval for dry use only and immediately began the process to obtain approval for use in carbonated beverages as well. ${ }^{35}$

G. D. Searle filed a petition on September 27, 1982, for the use of aspartame in carbonated beverages. In public statements, Searle declared that the chemical had been tested and found stable in soft drinks. At the time of the petition, South Africa and Canada had already approved the use of aspartame for human consumption in carbonated drinks..$^{36}$ Although several objections were brought to the attention of the FDA, those protesters were dismissed and denied a public hearing due to lack of evidence regarding its safety. The courts argued that safety issues were resolved during the initial approval of aspartame in I98I and did not need to be revisited. ${ }^{37}$ In I983, without

33 "Low-Cal Aspartame: The New Kid in Town," Science News I2O, no. 4 (I98I): 54. http://www.jstor.org/stable/3965996.

34 Jeffery Smith, “Aspartame Approved Despite Risks," Science 2I3, no. 45II (I98I): 986-987. http://www.jstor.org/stable/r687044.

35 Eva Hoffman and Margot Slade, "Ideas \& Trends: In Summary F.D.A. Approves A Competitor For Saccharin," New York Times, July 19, 1981, E22. http://www. nytimes.com/rg8r/o7/rg/weekinreview/ideas-trends-in-summary-fda-approves-acompetitor-for-saccharin.html.

36 "Searle Sweetener," New York Times, September 28, 1982, Dio. http://www. nytimes.com/rg82/og/28/business/searle-sweetener.html.

37 Lars Noah, "Legal Aspects of the Food Additive Approval Process," in Enhancing the Regulatory Decision-Making Approval Process for Direct Food Ingredient Technologies, (Washington DC: The National Academy Press, 1999), I627. http://www.nap.edu/openbook.php? record_id $=9453$ \& page $=39$. 
significant evidence against the safety of aspartame in liquid form, Hayes approved its use in beverages and syrup. ${ }^{38}$

Several months after the approval of aspartame in liquid form, Arthur Hull Hayes Jr. resigned as commissioner of the FDA after being personally investigated in connection with irregularities in his travel vouchers. ${ }^{39}$ Hayes was found to be taking benefits, namely the use of a private jet owned by General Food Corporation, a major distributer and user of NutraSweet. Accepting incentives from a company so closely related to his recent approval caused the FDA and many of his colleagues to question his neutrality and integrity. In 1986, Hayes accepted a position with E. M. Industries and served as a Senior Scientific Consultant with Burson-Marsteller. The public relations firm of Burson-Marsteller represented NutraSweet and several major users of aspartame, but Hayes claimed to not have discussed aspartame during his time at the company and no substantial evidence of misconduct could be documented. ${ }^{4}$

From the initial approval of aspartame in 1974 until the final approval in 1983, many changes in FDA personnel occurred. Hayes and Rumsfeld were not the only two officials to be simultaneously involved in government and big business. Several officials involved in key decisions regarding the status of aspartame left their jobs with the FDA and accepted positions with companies closely linked to aspartame and its production. Sherwin Gardner signed for its approval in 1974 and resigned from the FDA in 1979 to take a job as Vice President of Grocery Manufacturers of America, Inc., a large distributor of aspartame. Stuart M. Pape served as a Special Assistant to the FDA Commissioner from 1976 to 1979 but later left to take a position with the law firm of Patton, Boggs, and Blow, a firm that worked closely with the National Soft Drink Association, many times addressing aspartame. Dr. Howard R. Roberts worked as the Deputy Director of the Bureau of Foods. During his employment, he worked closely with the Public Board of Inquiry in 1980 and personally

38 Jane E. Brody, "Judging Safety of Aspartame in Soft Drinks," New York Times, July I3, I983, CI. http://www.nytimes.com/r983/o7/r3/garden/personal-healthjudging-safety-of-aspartame-in-soft-drinks.html.

39 "National Report: FDA Commissioner Resigns Under Fire," Chicago Tribune, July 29, I983, 8. Proquest Historical Newspapers (I75962550).

40 David P. Baine, "Report to the Honorable Howard Metzenbaum, US Senate. Food and Drug Administration: Six Former HHS Involvement in Aspartame's Approval" (GAO/HRD-86-IogBR) (Washington, DC: U.S. Government Accountability Office, I986) http://www.gao.gov/assets/80/75806.pdf. 
reviewed G. D. Searle's studies pertaining to aspartame safety. In I978, Roberts left to become Vice President for Science and Technology at the National Soft Drink Association. Robert A. Dormer was formerly the trial attorney for Health and Human Services between 1976 and 1979, participating in several cases relating to aspartame. After leaving his position, Dormer was hired by the law firm of Hyman, Phelps, and McNara, a firm that provided legal advice to G.D. Searle. All four of the men contacted the FDA after their resignations on behalf of their new companies, but only Roberts, Pape and Dormer were confirmed to have discussed aspartame. Ultimately, these men accepted prestigious positions with companies they had communicated with and assisted during their employment with the FDA. The seemingly quick trust and responsibility given to these men by their new employers further reveals and emphasizes the fine line between big business and government officials. ${ }^{4}$

\section{Aspartame's Approval Impacts the Sweetener Market}

Despite the possible corruption involved with its approval, aspartame's popularity grew exponentially. By I983, the aspartame sugar substitute branded Equal was dominating the table-top sweetener market with a net worth of \$150 million, surpassing former saccharin-based leader Sweet'N Low. Soft drink companies took notice of the new artificial sweetener and adjusted accordingly. The advantages of switching sugar substitutes included the fact that, unlike saccharin, aspartame required no safety label in I983. Also, aspartame appealed to diabetics because its protein composition did not require insulin to be metabolized. Lastly, this substitute tasted more like sugar than other sweeteners and cost a fraction of the price of pure sugar. Even so, aspartame was still considerably more expensive than its competitor saccharin. To maximize profits, Coca-Cola and Royal Crown announced they would use a combination of the two artificial sweeteners in their low calorie products. In I984, just one year after complete approval was granted, 6.9 million pounds of aspartame were consumed in the US. ${ }^{42}$ A decade earlier, Searle's stock had plummeted after cancer became associated with aspartame. After hiring Donald Rumsfeld, who influenced aspartame's final approval in I982, G.D.

4I US Food and Drug Administration, Six Former HHS Employees' Involvement, http://archive.gao.gov/d4t4/130780.pdf.

42 Pamela G. Hollie, "Aspartame Builds a Market," New York Times, September 3, I983, 29. http://www.nytimes.com/I983/o9/o3/business/aspartame-builds-a-market. html. 
Searle regained their momentum. NutraSweet quickly became a highly profitable portion of G. D. Searle and between I98I and I982, sales increased from $\$ 13$ million to $\$ 74$ million. By 1983, sales reached $\$ 336$ million, and NutraSweet was responsible for thrity-four percent of Searle's profits that year. As the market for diet products rapidly expanded, consumers became less influenced by safety concerns and G. D. Searle thrived financially. ${ }^{43}$

While many US consumers were enthralled with the new artificial sweetener, some skeptics remained unconvinced of its safety and continued to actively research the effects of aspartame, especially in liquid form. Dr. Woodrow Monte dedicated his life to studying food ingredients and products and their impact on human health. After conducting several experiments at Arizona State University, Monte found that aspartame, specifically in unstable, liquid forms, caused health dangers far beyond what was documented. He filed an objection against aspartame's approval in soft drinks due to links with methanol poisoning. Ingesting as little as two teaspoons of methanol can be fatal in humans, yet Monte found that methanol is a component found in aspartame. When consumed, methanol is released into the small intestine after the hydrolysis of the methyl group breaks down the dipeptide. Within hours after consumption, approximately ten percent of the aspartame consumed is converted to methanol and enters the blood stream. Additionally, since aspartame in liquid form is not stable, sodas in storage have the ability to decompose on their own and release methanol, especially when exposed to high temperatures. The methanol ingested during moderate aspartame consumption would be unlikely to cause death, but Monte explained that the amount found in just one liter of diet soda is significantly higher than the Environmental Protection Agency's daily limit recommendation. ${ }^{44}$

Monte compared side effects of excessive exposure to methanol found in Public Health Service reports to the symptoms reported in complaints from aspartame users. After studying individuals exposed to environments with high methanol content, Public Health Services found that methanol exposure could lead to headaches, dizziness, numbness, and a multitude of vision problems. Hundreds of aspartame consumers reported similar symptoms to the Centers

43 "Searle (G.D.) \& Co.," Encyclopedia of Chicago, http://www.encyclopedia. chicagohistory.org/pages/2839.html.

44 Woodrow Monte, "Report Aspartame: Methanol and the Public Health," Journal of Applied Nutrition 36 (I984): 4. http://dorway.com/doctors-speak-out/ aspartame-methanol-the-public-health/. 
for Disease Control in Atlanta. ${ }^{45}$ With this data, Monte was confident that the similarities were not coincidental. Though he recognized that drinking a diet soda occasionally, or even regularly, would not be lethal, the lack of long-term experiments documenting the effects of regular methanol consumption concerned him. Monte's findings led to his request for a public hearing regarding aspartame's safety in beverages. ${ }^{46}$ After his findings spread throughout the Arizona State University community, G. D. Searle sent lobbyists to Arizona Legislators, causing Monte's request for a hearing to be denied. Searle responded to the findings by claiming that more naturally occurring methanol is released from fruits and vegetables than from aspartame. Monte retorted by explaining the methanol released naturally from fruits and vegetables is also accompanied by a release of ethanol, which counteracts the methanol in the body, making the consumption far less dangerous. Aspartame decomposition contains no ethanol to counteract the methanol. ${ }^{47}$ Without the support of the FDA, however, Monte was unable to pursue his allegations. Even so, his research and conclusions were widely noticed, encouraging the government to once again investigate the safety of aspartame. Even today, Monte is still conducting research and publishing books and articles to inform the general public of the potential health risks of aspartame.

\section{Safety Concerns Arise Once Again}

Ohio Senator Howard Metzenbaum proposed the Aspartame Safety Act of 1985, which required a disclosure of the quantity of aspartame present in any product. Known for his liberal views and support of labor unions, Metzenbaum was dissatisfied with the way big business manipulated aspartame's safety approval. Metzenbaum's motivation for introducing the bill was based upon Monte's findings. He thought warning consumers of the amount of aspartame found in food products could help educate the public without banning the substance altogether. With the existence of several lawsuits against G. D. Searle, along with hundreds of complaints filed to the Centers for Disease Control and the potential for brain damage found after consuming large amounts of aspartame, Metzenbaum strongly

45 Daniel P. Puzo, "Complaints on Aspartame Lead to Nationwide Investigation," Los Angeles Times, July 5, I984, Ir. Proquest Historical Newspapers (I5391767I).

46 Monte, "Report Aspartame," 4.

47 Nancy Yoshihara, "NutraSweet: A Big Taste of Success," Los Angeles Times, April I2, I985, BI, http://articles.latimes.com/I985-04-I2/news/mn-7766_I_sugarsubstitute. 
emphasized the need for adequate labeling. Unfortunately, after being sent to the Senate floor, the bill failed by a 68-27 vote..$^{8}$

When questioned about the backlash and complaints from users of aspartame, G. D. Searle responded that they actually expected more complaints than they received. Out of 70 million users, only six hundred consumers formally filed complaints. In all interviews referencing the harmful side effects caused by aspartame, G.D. Searle's employees dismissed the symptoms as a coincidence and always supported the chemical's safety. In 1985, Dr. Sturtevant of G.D. Searle told the New York Times, "We have no objection to the FDA requiring quantitative labeling of food ingredients in general, but we do object to FDA singling out aspartame because there is no scientific evidence suggesting it need be." ${ }^{49}$

Even without support from the FDA, skeptics of aspartame have continued to research its undesirable effects throughout the last few decades. In an article in the Star Tribune, the National Institutes of Environmental Health Sciences revealed that their scientists had requested grants to further investigate aspartame without the influence of the NutraSweet Company. These requests were filed between 1980 and 1994 , but the FDA denied all four proposals because officials insisted the product was already proven safe and unless new scientific evidence was brought forward (extra tests would be redundant.) When interviewed about the subject, David Rall, who worked for the NIEHS for 19 years, found the opposition of further safety studies by the FDA simply irresponsible. Rall and many other scientists agreed that updated testing on such a popular product was absolutely necessary to ensure safety. ${ }^{\circ} \mathrm{Dr}$. John Olney also continued his research and in 1996 published his results in the Journal of Neuropathology and Experimental Neurology. Those studies documented a startling increase in brain tumors and brain cancer since the approval of aspartame's use in carbonated beverages in 1983. Olney was convinced of the link between the two..5 Without support from

48 David Shribman, "Senate Continues Block of FDA Ban on Saccharin Use," Wall Street Journal, May 8, I985, http://www.gpo.gov/fdsys/pkg/CRI-r985/html/CRII985-SACCHARIN-STUDY-AND-LABELING-ACT.htm.

49 Marian Burros, "A Sweetener's Effects: New Questions Raised," New York Times, July 3, 1985, CI http://www.nytimes.com/1985/07/03/garden/a-sweetner-seffects-new-questions-raised.html.

50 Greg Gordon, "FDA Resisted Proposals To Test Aspartame," Star Tribute, November 22, 1996.

5I John Olney, "Increasing Brain Tumor Rates: Is There a Link to Aspartame," 
the FDA, however, much of the general public remained unaware of these findings.

Although a great deal of controversy continues to surround aspartame, health concerns have failed to hinder the success of G. D. Searle. Indeed, NutraSweet has become an international billion-dollar company. NutraSweet's goal was always to market its product directly to consumers with positive advertising. Their tactics have been wildly successful. In America, approximately I7,I00,000 pounds of aspartame were consumed in 1987 , and a majority of that intake was in the form of diet carbonated beverages. After 1987, NutraSweet stopped releasing consumption data to the USDA..$^{52}$ Before NutraSweet's patent on aspartame ended in December I992, the company carefully negotiated with Coca-Cola Co. and Pepsi-Cola Co. to convince them both to sign a contract promising that NutraSweet would remain their preferred manufacturer of aspartame for use in their diet beverages. This contract guaranteed that NutraSweet would maintain their monopoly on aspartame production even after their patent expired. According to Richard Nelson, a spokesperson for NutraSweet, by 1992 soft drinks were responsible for seventy-five percent of the aspartame consumed in the United States. A contract with the two largest soft drink companies solidified the prolonged success of NutraSweet. Today on NutraSweet's website, the company brags of the sweetener's availability in over 100 countries and its consumption by 250 million people. ${ }^{53}$ Even with the introduction of a new sugar substitute branded Splenda in 2000 , aspartame still dominates the market.

Although little legal action has been taken against aspartame recently, the growing popularity of the internet over the past twenty years has enabled consumers to become more aware of its possible harmful side effects. In I995, an internet hoax was created to warn consumers of the dangers of aspartame. The website and emails were highly inaccurate and biased, but the email sparked conversation about possible symptoms related to the consumption of the substance. ${ }^{54}$ Numerous blogs and websites today are committed

Journal of Neuropathology and Experimental Neurology 55 (1996): III5-II23, http:// www.ncbi.nlm.nih.gov/pubmed/8939194.

52 Janny Scott, "The Promises and Perils of Designer Foods," Los Angeles Times, October 8, 1989, Q57. http://articles.latimes.com/I989-I0-o8/magazine/tm-46_I_foodengineering.

53 "NutraSweet Overview," The NutraSweet Company, accessed February i6, 20I4, http://www.nutrasweet.com/company.asp.

54 "Aspartame Controversy," Wikipedia, accessed February 20, 20I4, http:// 
to providing "facts" about it, and while they can provide valuable information, many are still plagued with biases. If the reader can successfully navigate between the facts and embellishment, these websites can be useful resources. Janet Starr Hall, writer of Sweet Poison, has dedicated her life to warning the public about aspartame through her book and website. While her website is obviously antiaspartame, she strives to utilize facts to validate her claims..$^{55}$

Technology has exposed American society to an infinite number of daily dietary choices. The nation's food footprint has expanded to lengths that previous generations could not imagine. With the plethora of opportunities and options, consumers must make educated decisions about what they put into their bodies. This paper illustrates that although the government and the FDA is charged with keeping unsafe products off the market, some still slip through the cracks. No system is perfect and big business will continue to influence government decisions if citizens remain uninvolved and choose to look the other way. Unfortunately, just because a product is legal does not necessarily mean it is safe, especially in large quantities. By being aware of and educated about the food they eat, hopefully people can successfully eat healthier and limit the amount of unsafe chemicals in food. As Michael F. Jacobson, Executive Director of the Center for Science in the Public Interest, stated in 2006, "For a chemical that is used by hundreds of millions of people around the world, it should be absolutely safe, there shouldn't be a cloud of doubt." ${ }^{6}$

en.wikipedia.org/wiki/Aspartame_controversy.

55 Janet Starr Hull, “Aspartame Dangers Revealed,” Sweet Poison,accessed February 20, 20I4, http://www.sweetpoison.com.

56 Melanie Warner, “The Lowdown on Sweet?” New York Times, February I2, 2006. http://www.nytimes.com/2006/02/12/business/yourmoney/r2sweet. html?pagewanted=print\&_r=o. 


\section{BIBLIOGRAPHY}

Brody, Jane E. "Judging Safety of Aspartame in Soft Drinks." New York Times, July I3, I983, Cr. http://www.nytimes.com/1983/o7/I3/garden/personal-healthjudging-safety-of-aspartame-in-soft-drinks.html.

Burros, Marian. “A Sweetener's Effects: New Questions Raised.” New York Times, July 3, I985, CI http://www.nytimes.com/1985/07/03/garden/a-sweetner-s-effectsnew-questions-raised.html.

Chapman, Stephen. "Can Rumsfeld Add Another Line To A Strong Resume?" Chicago Tribune, February 15, I987, $\mathrm{C}_{3}$. . http://articles.chicagotribune. com/1987-02-15/news/870II20628_I_donald-rumsfeld-white-house-secretservice.

Cloninger, Marion R. and Ruth E. Baldwin. "Aspartylphenylalanine Methyl Ester: A Low-Calorie Sweetener.” Science I70, no. 3953 (I970): 8I-82. http://www.jstor. org/stable/I730I76.

Cockburn, Andrew. Rumsfeld: His Rise, Fall, and Catastrophic Legacy. New York: Simon and Schuster, 2007.

“Controversy Over New Sweetener." Science News II6, no. 6 (I979): I03. http://www. jstor.org/stable/3964327.

Federal Drug Administration. Recall Aspartame as a Neurotoxic Drug. By Mark D. Gold. FDA Docket o2 P-0317, 2003. http://www.fda.gov/ohrms/DOCKETS/ dailys/o3/Jano3/or2203/o2P-0317_emc-ooorg6.txt.

Freeman, Martha M. "The Role of Clinical Guidelines in Research: FDA's Viewpoint." The Journal of Clinical Pharmacology I7, no. II (I977): 682-685.

Gordon, Greg. "FDA Resisted Proposals To Test Aspartame.” Star Tribute, November 22, 1996.

Government Accountability Office. Report to the Honorable Howard Metzenbaum, US Senate.: Six Former HHS Involvement in Aspartame's Approval (GAO/HRD86-rogBR). By David P. Baine. Washington, DC: U.S., I986. http://www.gao. gov/assets/8o/75806.pdf.

---. Report to the Honorable Howard M. Metzenbaum. US Senate:Food and Drug Administration Food Additive Approal Process Followed for Aspartame. (GAO/ HED -87-46). By Martin J. Socolar. Washington DC: U.S., I987. http:// archive.gao.gov/d28t5/13346o.pdf.

Hoffman, Eva and Margot Slade. "Ideas \& Trends: In Summary F.D.A. Approves A Competitor For Saccharin.” New York Times, July 19, I981, E22. http:// www.nytimes.com/rg8I/o7/19/weekinreview/ideas-trends-in-summary-fdaapproves-a-competitor-for-saccharin.html.

Hollie, Pamela G. "Aspartame Builds a Market.” New York Times, September 3, I983, 29 http://www.nytimes.com/1983/o9/o3/business/aspartame-builds-a-market. html. 
Hull, Janet S. "Aspartame Dangers Revealed." Sweet Poison. Accessed February 20, 20I4. http://www.sweetpoison.com.

---. Sweet Poison: How the World's Most Popular Artificial Sweetener Is Killing Us. Far Hills, NJ: New Horizon Press, I999.

La Pena, Carolyn D. Empty Pleasures: The Story of Artificial Sweeteners From Saccharin to Splenda. Greensboro, NC: The University of North Carolina Press, 2010.

Los Angeles Times. "A History of Saccharin.” December 27, 2010. http:// articles.latimes.com/20Io/dec/27/health/la-he-nutrition-lab-saccharintimelin2oror 227 .

Soceity for Science and the Public. "Low-Cal Aspartame: The New Kid in Town." Science News I20, no. 4 (I98I): 54 http://www.jstor.org/stable/3965996.

Merrill, Richard. "Regulating Carcinogens in Food: A Legislator's Guide to the Food Safety Provisions of the Federal Food, Drug, and Cosmetic Act." Michigan Law Review 77, no. 2 (I978): I9I-I95. http://www.jstor.org/stable/I287920.

Metcalfe, Ed. "Sweet Talking." The Ecologist 30, no.4 (2000): I6. http://search. proquest.com/docview/743764035.

Monte, Woodrow. "Report Aspartame: Methanol and the Public Health." Journal of Applied Nutrition 36, no. I (I984): 4. http://dorway.com/doctors-speak-out/ aspartame-methanol-the-public-health/

Chicago Tribune. "National Report: FDA Commissioner Resigns Under Fire”. July 29, I983, 8. Proquest Historical Newspapers (I75962550).

Nill, Ashley. "The History of Aspartame." Food and Drug Law/Third Year Paper Harvard Law School, Cambridge, 2000. Accessed February 15, 20I4 http:// dash.harvard.edu/bitstream/handle/I/8846759/Nill,_Ashley_-_The_History_of_ Aspartame.html? sequence $=6$.

Noah, Lars. "Legal Aspects of the Food Additive Approval Process." In Enhancing the Regulatory Decision-Making Approval Process for Direct Food Ingredient Technologies, 15-57. Washington DC: The National Academy Press, I999. http://www.nap.edu/openbook.php?record_id=9453\& page=39.

“NutraSweet-Not So Neat." Off Our Backs I4, no. 8 (I984): 8. http://www.jstor.org. ezproxy.lib.vt.edu:8080/stable/10.2307/.

"NutraSweet Overview." The NutraSweet Company. Accessed February, i6, 2014. http://www.jstor.org/stable/2579446r.

Olney, John. "Increasing Brain Tumor Rates: Is There a Link to Aspartame.” Journal of Neuropathology and Experimental Neurology 55, no. II (I996): III5-II23, http:// www.ncbi.nlm.nih.gov/pubmed/8939194.

Olney, John. "Medicine Alumni Society: Alumni Interview," The University of Iowa, accessed February I6, 20I4. http://www.healthcare.uiowa.edu/alumni/ interviews/olney_john.html.

Puzo, Daniel P. “Complaints on Aspartame Lead to Nationwide Investigation.” Los Angeles Times, July 5, I984, II. . Proquest Historical Newspapers (I539I767I). 
“Saccharin." National Toxicology Program. http://www.ncbi.nlm.nih.gov/pmc/ articles/PMCi637197/.

Scott, Janny. "The Promises and Perils of Designer Foods." Los Angeles Times, October 8, ı989, Q 57. http://articles.latimes.com/1989-I0-o8/magazine/tm46_I_food-engineering.

“Searle (G.D.) \& Co." Encyclopedia of Chicago. http://www.encyclopedia. chicagohistory.org/pages/2839.html.

“Searle Sweetener." New York Times, September 28, I982, Dio. http://www.nytimes. com/rg82/og/28/business/searle-sweetener.html.

Shribman, David. "Senate Continues Block of FDA Ban on Saccharin Use.” Wall Street Journal, May 8, I985, http://www.gpo.gov/fdsys/pkg/CRI-I985/html/ CRI-r985-SACCHARIN-STUDY-AND-LABELING-ACT.htm.

Smith, Jeffrey. "Aspartame Approved Despite Risks.” Science 2I3, no. 45II (I98I): 986987. http://www.jstor.org/stable/I687044.

Smyth, Todd R. "The FDA's Public Board of Inquiry and the Aspartame Decision." Indiana Law Journal 58, no. 4 (1983): 627-635. http://www.repository.law. indiana.edu.

“The Story of Sweet'N Low." Sweet'N Low. Accessed February I7, 20I4. http://www. sweetnlow.com/brand.

Turner, James S. Swankin and Turner: Attorneys at Law. Accessed February r6,20I4. http://www.swankin-turner.com/jim.html

US Food and Drug Administration. The Story of the Laws Behind the Labels. By Wallace Jannsen. http://www.fda.gov/AboutFDA/WhatWeDo/History/Overviews/ ucmo56044.htm

Warner, Melanie. “The Lowdown on Sweet?” New York Times, February i2, 2006. http://www.nytimes.com/2006/o2/I2/business/yourmoney/r2sweet. html?pagewanted=all.

Wikipedia. "Aspartame Controversy.” Accessed February 20, 20I4. http:// en.wikipedia.org/wiki/Aspartame_controversy.

Yoshihara, Nancy. "NutraSweet: A Big Taste of Success." Los Angeles Times, April I2, I985, BI, http://articles.latimes.com/I985-04-I2/news/mn-7766_I_sugarsubstitute.

\section{ABOUT THE AUTHOR:}

Morgan Sykes is a junior at Virginia Tech from Winchester, Virginia. She is majoring in history with a minor in psychology. Her passion is working with children and, after graduation, she plans to pursue a Master's degree in elementary education with an eye towards teaching at the elementary level. 